\title{
Binongko people's life in Coral Island
}

\author{
ABD. RAHMAN HAMID
}

\begin{abstract}
This article looks at the life of Binongko people. The word "Binongko" is well known as a Buton migrant's identity from Southeast Sulawesi in Maluku. In fact, it is a name of a rock island in Wakatobi district. Few people know about this fact. Binongko people built their world through the myth of La Patua Sakti and Putri Bidadari. Since the environment did not support farming activities, most of the people's needs were supplied by the sea through sailing. This activity was as old as their history in this island. The people also developed their skills as blacksmiths, which supported sailing tradition. This profession was an old identity of Wakatobi. This island brought about: early migrants of Buton in Maluku, skilful sailors, and ulamas, who were hard-working people. This study finds the relationships between the environment, history, and culture of Binongko people in Wakatobi area.
\end{abstract}

KEYWORDS

Binongko; migrant's identity; sailing tradition.

\section{INTRODUCTION}

Binongko is a name of an island located on the front side of Southeast Sulawesi Province, in Wakatobi district, located in the western part of the Banda Sea and north of Flores Sea. Before the arrival of the European people, the island was called by mainland Buton people as Liwuto Pasi (Rock Island). Besides Binongko, Wakatobi is also attached to three other islands in the surrounding areas, namely Wangi-wangi, Kaledupa, and Tomia. In the era of Buton monarchy, the four islands were called Liwuto Patanguna (four islands), and then in the Dutch colonial era it was changed into Toekangbesi Eilanden (the islands of blacksmiths). Lately, in the independence era, the four island names were made into an acronym Wakatobi, which stands for

ABD. RAHMAN HAMID, a PhD student in History, Faculty of Humanity, Universitas Indonesia. He got his MA in history from Hasanuddin University in 2007, with a thesis entitled "Pelayaran dan perdagangan maritim orang Buton di Kepulauan Wakatobi 1942-1999.“ His main publications include Sejarah maritim Indonesia (2013), Pembelajaran sejarah (2014), and SabangkaAsarope: tradisi pelayaran orang Buton (co-author Tasrifin Tahara, 2015). At the moment, he is writing a dissertation on the cruise of Mandar people in the straits of Makassar in the twentieth century. Abd. Rahman Hamid can be contacted at: abdul_pasca@yahoo.com

(C) 2016 Faculty of Humanities, University of Indonesia

ABD. RAHMAN HAMID | DOI: 10.17510/wacana.v17i1.451 
Wangi-wangi, Kaledupa, Tomia, Binongko, as a name of the district in the Southeast Sulawesi Province.

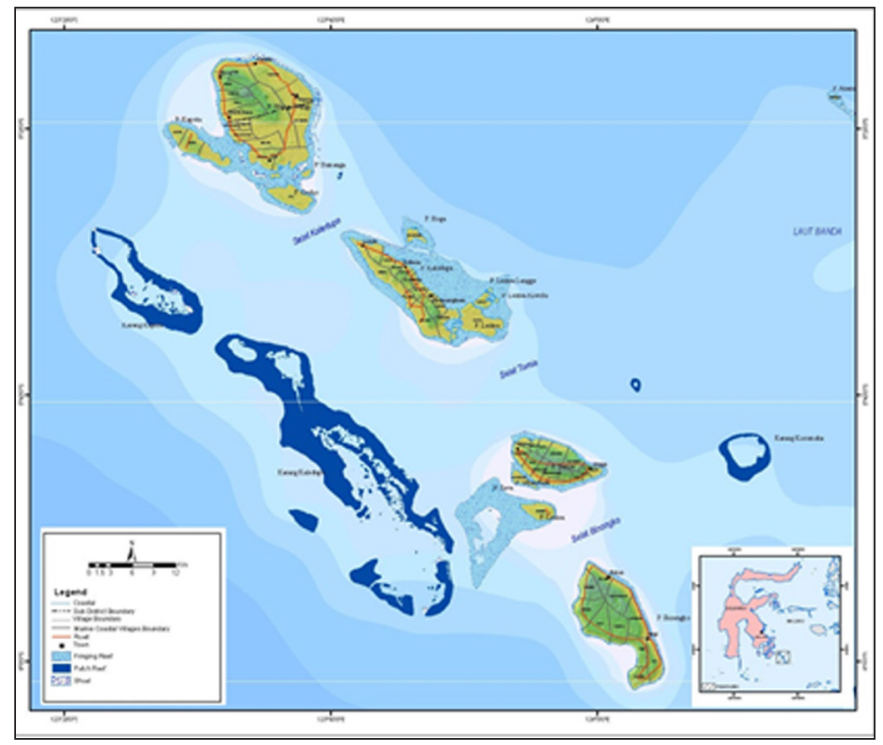

Map 1. Binongko Island in Wakatobi Regency (source: https:/ / www.google.co.id).

Binongko people are well known in Ambon, Maluku, as a group of Buton migrants, who have lived there for a long time. However, few people know about the Binongko Island as an origin of great sailors. All people coming from Southeast Sulawesi are often called or call themselves Binongko, although actually they do not come from Binongko. In addition, the word Binongko is also used as a name for various types of machete, which are known for their good quality among farmers there and which are sold by peddlers from Buton. Referring to the most recent information, there was an opinion that the type of machete used by Chief Pattimura, as printed on the 1000-rupiah note, is Binongko machete.

Compared to the other three islands in the Wakatobi district, Binongko is the most barren island, hard to access at the turbulent time of the sea, and the most underdeveloped area. For the first time after arriving at the island on 17 May 2007, I could not go out of the house without wearing my sandals because of the sharp rocky surface. From Rukuwa port, I took an ojek (motorcycle transport) through paths among the rocks to Wali village. On the second visit on 15 March 2015, the road's condition seemed to be improved as it was paved with asphalt already. The road was wider, about three to four meters wide. The trip by an ojek from Bante port to Wali was better than it was during the first visit.

The water quality used by the local people for their daily activities was still the same: it tasted a bit salty. The water was taken from pits or holes in the rocks. The best time to take the water was when the tide ebbed because when the tide rose, the water in the hole tasted saltier. That is why in the past 
water was the most important help for people who had a party. No wonder that many earthenwares or ceramic jugs, which were brought by sailors from Singapore, could be found at every house to accommodate water in the rainy season. Some families made big water pools to accommodate rain for their needs in the dry season. Meanwhile, electricity was limited only for the night, starting from 6 p.m. to 12 p.m. Therefore, family activities that relied on electricity could only be carried out at night, except for few people who already had their own generators. Thus, people only used electricity that was provided by the state electricity company (shortened PLN in Indonesian) for only six hours a day.

The condition influenced the Binongko people's way of life. Why did people inhabit this island? How could they survive? Where did they get their daily supplies? Then, why did not they move to another more fertile island? Many questions could be asked. Moving from the questions, this article tries to explain the survival strategies of Binongko people in the rock island for hundreds of years. In anthropological perspective, human beings' success to master their natural environment is proof for their success in achieving a higher level of culture (Poerwanto 2005: 87).

\section{EARLY CONDITION OF WAKATOBI}

In the past, a man came from China named La Patua. He was sailing around the world by a great ship. He wanted to see whether the world was a perfect creation or not. He was a descendant of Noah. When his ship sailed at night, shiny light appeared from the peak of the island, which hindered him from mastering his ship so that it hit the rock. Using a small boat, he tried to paddle away from the ship to the point where the light came from. In fact, the light was emanated from the head of a princess dancing on the island. On her head was attached a crown and on her ears sparkling earrings. In their meeting, each of them used secret codes (haebu) of their own, but they could understand each other. The codes were later on developed into languages used by the people of Binongko Island. The language used by La Patua is called Cia-cia, while the language of the princess is called Kaumbedha. ${ }^{1}$

The meeting place of La Patua and the princess was Binongko Island, as is believed by its people as Pocuno Wuta (Chief of the land). This island has rocks and salty water. The name "Binongko" comes from two words: Bi (the embodiment of the princess' head) and Nongko (the embodiment of La Patua's ship).

After the meeting, La Patua continued his sailing to the north. At dawn, he saw a man (omia/mia in Cia-cia language) and heard a mysterious voice temia 'there was a man' (in Kaumbedha language). Then, he continued his journey further to the north and saw an island. On that island, he saw white smoke accompanied with a smell of incense (dhupa) coming out of the navel of a princess floating on the sea. Watching the miracle, La Patua bowed and

1 The story about La Patua and the princess is derived from the work of La Rabu Mbaru. 2005. The Story of Haebu of Bitokawa Islands, Butuni at Magical Time [manuscript]. 
prostrated for the greatness of the Creator. From this event came the word kahe (land) and dhupa (incense), later on became the name Kahedhupa or Kaledupa Island, which means 'fragrant land' (Hamid 2011: 39). Near the Kaledupa Island, La Patua saw a light of life emanating from the princess which then changed into an island full of secrets. That was the Hoga Island, the Life Island.

After observing Kaledupa and Hoga, La Patua continued his sailing to the north up to Wanianse waterways. At that time, this island was still invisible. What could be seen was only a tall figure or Wa Langka Tu'u (the man with long knees). When Wa Langka Tu'u stepped forward, a fragrant smell spread accompanied with the appearance of the islands (Kapota, Toue, Kompono One, Pohara, Somanga, Simpora, Watu Nua-nua, and Watu Napabale). From this story, the name Wangi-wangi Island was born, which was previously called Wanianse. The people of this island are often called Wanci or Wanse. Another version said that the fragrance came from the incense in Kaledupa, which was the princess (Mbaru 2005: 5).

The short story mentioned above reflected autonomy in the narration of the Binongko identity, as the origin of identity formation of the islands of Binongko, Tomia, Kaledupa, and Wangi-wangi. Based on the story, an old acronym was created for Wakatobi islands, namely Bitokawa (Binongko, Tomia, Kaledupa, Wangi-wangi). As mentioned earlier, mainland Buton people call the four islands as Liwuto Patanguna, and the people are called orang pulo (people of island). So is the case with its language, which is called bahasa pulo (island's language). The spread of Kaumbedha language, as a major group in Wakatobi, could be seen in the story of the Princess. While La Patua, as a figure that passed down the Cia-cia language, after arriving at Wanianse, went back to Binongko. Therefore, Cia-cia language is limited to some Binongko people.

Another interesting matter is the association of the human body used as a signifier of each Wakatobi Island. It started from Binongko, which was signified by the head. Then, Tomia as the chest, Kaledupa as the stomach, and Wangi-wangi as knee and feet. In terms of physical characteristics, the head consists of hard bones and very little flesh. Therefore, Binongko is the most barren island. The chest (Tomia) and stomach (Kaledupa) are the soft parts of the body, so both islands are more fertile than Binongko and Wangiwangi. Knee and feet indeed consist of hard bones, but they have more flesh than the head. That is why Wangi-wangi is also more fertile than Binongko.

The mystical mind in Binongko is dominant. Caleb Coppenger (2012: 182) recorded that, using a magical power, Binongko people can hold a burning iron from the furnace without using any pincers and can forge metal into a spear using bare hands when needed. In the island, there is a hole that can capture a shadow and drag people into it. Another mystical story is related to the sarong weaving, which started from the early existence of the Binongko Island up to present.

Besides the mystical aspect, Binongko was also renowned for its history of Islam spreading. Binongko received Islam much earlier than the other 
islands, so it is called the "Porch of Mecca" of Wakatobi or Buton (Hamid 2011: 67). After spending eight years converting Binongko into Islam, Syekh Abdul Wahid continued the spread of Islam in Buton. Binongko people's sense of religiosity was very strong. In the end of the nineteenth century and the beginning of the twentieth century, Binongko people went on a pilgrimage to Mecca by a sailboat. This journey of going back and forth took nine months. Then, in the middle of the twentieth century, famous ulamas, such as Kiyai Haji Asy'ari, Kiyai Haji Ibrahim, Kiyai Haji Abdul Syukur, and Kiyai Haji Daud appeared. Kiyai Haji Asy'ari was once a mosque leader of Bau-bau, Al-Fatah Ambon, and Irian Jaya (Hamid 2011: 67-68). Meanwhile, the other three ulamas were enthusiastic in spreading their religion in Southeast Sulawesi. This perhaps explains why Binongko people as well-known to be strongly devoted to prayers. In 2004, I found an Al-Quran reading teacher and an Islamic missionary from Binongko in Kendari, Southeast Sulawesi Province. His name is Hasan Husain, and he was active in spreading Islam from one prayers' group to another. In short, besides living in a mystical world, Binongko people also had a strong Islamic devotion.

\section{LANGUAGE AND ETHNICITY}

Based on the story above, the historical roots of language and ethnicity in Binongko came from the story of La Patua and the Princess. Nonetheless, language experts grouped the two dialects into one category, namely the language of the blacksmiths, with four different dialects: Wangi-wangi, Kaledupa, Tomia, and Binongko (Noorduyn 1991: 131).

The language of the blacksmiths has similarities with the language of the people in Bonerate Island and surrounding islands in Flores Sea, namely Selayar district. Therefore, Noorduyn (1991) grouped it as belonging to the language of the blacksmiths and Bonerate. According to La Gani, ${ }^{2}$ a prominent public figure of Binongko people, who once lived on Madu Island, Selayar, the majority of people in the island spoke Binongko language. Burhanuddin, a staff in the Religious Office of Selayar and was stationed in Bonerate, said that some of the people living on Madu Island came from Binongko (Hamid 2011:332). Meanwhile, La Malihu, ${ }^{3}$ a lecturer of history at the State University of Makassar, who once sailed to Selayar Islands in 2003, met many speakers of Binongko language in Bonerate and Kalatoa.

Based on the data from E. van den Berg, when he visited the islands of the blacksmiths in 1938, the language used by Binongko people in the southeastern part was different from the language used in other regions, also from the three other islands in the blacksmiths (Noorduyn 1991: 132). In 2007 and 2015, when doing a research there, I found two languages in Binongko, namely Kaumbedha and Cia-cia. Kaumbedha language is used by the majority of Wakatobi people. Apart from Binongko, Cia-cia language also existed in the city of Bau-bau, Buton district, and South Buton district. 
The Binongko people at first inhabited the areas along the shorelines. However, because they were often attacked by pirates, especially from Tobelo area, North Maluku, they moved to the mountains or the peak of Binongko. They made use of and built fortresses of rocks that looked like a village. Inside the fortresses they lived and farmed. Some of the old Binongko villages, among others, are Mokoro, Kaluku, Komba-Komba, Wicu-wicu, Kandoro, Kambura, and Ndanga. In 1916, the number of taxpayers in Binongko was 2,519 people, with only two tax officers to collect the tax, namely La Ode Palisu and Haji Jama (Zahari 1977, III: 103-104).

In the beginning of 1960s, the government was keen on moving the people back to the shorelines because their existence on the mountains was isolated. In 1961, the government conducted a population census. A massive relocation happened in the end of 1961, with the help from the police mobile brigade company 597 stationed in Makassar led by Padabin Hasdara. Since that time, new villages such as Popalia, Taipabu, and Rukuwa/ Palahidu for Kaumbedha group, and Wali, Oihu, and Mole for Cia-cia group were formed. They helped each other in organizing the dwelling place and building houses. Until the beginning of 1962, people's houses had managed to be built. ${ }^{4}$

The 1961 census result showed that the population of Binongko was 10,985 . The population of Cia-cia was 4,044 , while that of Kaumbedha was 6,941 (PPSK UGM. 1980: 152). From the data, it can be concluded that the population has always been fluctuating. In 1973, there were 11,900 people, then it decreased into 10,682 in 1982 and increased again in 1990 into 11,613 people (BPS 1982: 23, 1987: 273). In 2010, it increased into 13,117. Three years later, in 2013, there were 13,242 people: 6,877 Kaumbedha people and 6,365 Cia-cia (Hadara et al. 2014: 42).

The frequent change of the population data above has some meanings. First, the natural condition of Binongko made its people move out to other places. Their children were born and grew in those new places. Therefore, they were not recorded. Second, sailing and trading activities caused them, especially men, to be away from the island. When the census was taken, they were not recorded. Third, irregular census, especially due to bad weather, made it difficult for census-takers to access this island. As a result, the population data were not accurate (Hamid 2011:78). The three factors affected the frequently changing population data.

\section{THE LIFE IN ROCKS ISLAND}

\section{FARMING AND BASIC NEEDS}

On 16 March 2015, between six and seven a.m., I saw some farmers going to the garden, bringing wooden carts containing household garbage to be thrown into the garden. Since land availability was very limited, the farmers took dry leaves and wood pieces around them to be made as land resources (katambari).

4 An interview with La Gani S (79 years old) in Taipabu village, 18-3-2015 and La Isihaka (73 years old) in Jaya Makmur village, 21-3-2015. 
On that day, around eight o' clock a.m., La Rabu Mbaru and I went to the Wa Ode Gowa beach in Wali village. We saw the barren natural condition of Binongko, full with rocks, and only very little land. There were just a few trees grown and very few that grew tall. On the mountain top, we saw only rocks and little grass. That is how the Binongko Island looks like.

On the roadside, an old woman was cleaning the yard and then planting cassava ( $k a s u b i)$. What interested us is the way she planted it. At first, the soil was loosened and made into a mound. Then, pieces of cassava, each $20-30$ $\mathrm{cm}$ long, were put into the loosened soil. The cassava stalk should not touch the bottom (rock), lifted about $5 \mathrm{~cm}$ from the bottom in order not to wither and to allow it to grow sideways.

It took a year or more to harvest the cassava. To come to terms with such a harsh condition, the farmers did not plant or harvest at the same time, like what is usually done on fertile ground. That is why, the planting and harvesting seasons are not the same at one yard. By so doing, when some parts of the yard are harvested, there are some others for backup for the next harvest.

There were two ways Binongko people prepare cassava into food. First, the cassava is cleaned beforehand, then it is steamed. After that, it is ready to be served. Second, the cassava that has been cleaned is cooked into kagepe ${ }^{5}$. The cassava's skin is scraped, then it is squeezed to extract its milk (by gripping or gepe) until it is dried. Next, the kagepe is scattered and put into the molding container, pyramid-like shaped, to be steamed until it is well-cooked into kasoami. In order for the kasoami to stay fresh, up to one month or more, before being cooked, the scattered kagepe is mixed with coconut oil and onion, then it is steamed until it is well-cooked. After that, the kasoami is smashed (pepe) to be solid. It is called the kasoami pepe ('kasoami that is smashed').

Besides the kasoami pepe, cassava could be preserved long in dried form. The cooking process is as follows: after its skin is peeled, it is dried up under the sun. The cassava colour will change from white into blackish white. Therefore, this cassava is also called black cassava (kasubia kito). The preservation period for this cassava is longer than for the kagepe and the kasoami pepe. The cooking process is similar to the newly harvested cassava, namely being boiled. Besides being consumed at home, this cassava serves as supply for the sailors in their far and long-sailing trip.

Another staple produced from local farming is corn. Corn can be harvested when it is unripe or ripe, and dried. Corn can be preserved for a long time and cooked into various kinds of food, such as dried cassava and kasoami pepe. Old corn after being cooked can be preserved for a long time and is much consumed by sailors. Another crop is banana. Compared to the previous two, banana cannot stay fresh for long. Therefore, banana is only consumed in a short time.

Binongko's natural environment does not allow the people to rely only on farming. Various families' needs are supplied from outside the island.

\footnotetext{
5 The word ka refers to grated cassava and gepe means being pressed. Thus, kagepe is grated cassava that is pressed.
} 
On a sailing season, diverse products such as rice, sugar, flour, and oil (palm and kerosene) are imported from Java. Other needs, like salt and onion, are imported from Nusa Tenggara, when sailors visit the area. Usually, after unloading in Java, on their way back home, the ships would go along the coast and drop by Nusa Tenggara. At the very moment, they would get fresh water, buy some salt and onion for family needs and for sale to other people. ${ }^{6}$

Up to the present, Binongko's ships take wood from mainland Buton and Maluku to Nusa Tenggara. A shipowner in Haka village $\mathrm{e}^{7}$ said that every time his ship returned from Nusa Tenggara, it would bring hundreds of coconuts for his family's need for the whole year. Other needs like rice, sugar, and flour can now be imported from Buton and Kendari through a regular ship cargo. In short, many of the people's needs are imported from outside Binongko by sea.

\section{HOUSE BUILDING}

In the past, people's houses were made of wood. Stilt houses were built on the rocks. Then, on the second half of the twentieth century, concrete houses started to be built stilt. In this case, there was a mix of old and new design. The front part was made without a stage, while the back section had a stage that functioned as a kitchen. For the old design, people took the materials from the surrounding environment, while the materials for the new ones were obtained from outside the island. Therefore, a big capital is needed and it takes a longer time to build concrete houses. Building time usually depends on the availability of materials.

Before building a concrete house, the person needs to sail and trade. On a sailing season, the house materials are obtained from outside the island. On the western wind season, ships sail to Maluku taking copra to Java and to Singapore on the eastern monsoon season. From Java, after the load is sold, they would buy various families' needs. For those who are going to or in the process of building a house, the main materials they need to buy are cement and roof-tiles.

Every year, ships sail at least once back and forth. Thus, there is only one chance to import building materials. That is also limited in quantity because the ship also brings other goods for family's and consumers' needs. As a result, building a house may take a year at the fastest, but generally more than a year not only for concrete but also for wooden houses since some materials have to be imported from outside the island.

Traditional sailing heritage, especially roof-tiles, can still be presently found at Binongko people's houses. The roof-tiles, which were once bought from Java, are kept beside the main house (stone-house) or under the house column (stilt-house). Some people use the roof-tiles for the roof of a small house that is used as a kitchen.

Different from building "the first house" that needs a year or more at the fastest until it is ready to be used, building "the second house" starts earlier

An interview with Haji Rusdin (60 years old) in Popalia village, 20-3-2015

An interview with La Banisa (50 years old) in Haka village, 17-3-2015 
before it can be used as a resting place for the deceased. In this context, the first house means a dwelling place for a family in this world, while the second house is a dwelling place for the dead or the family's burial place.

The condition and duration of building the second house do not apply to all regions since they are highly affected by natural circumstances. For instance, in Wali and Jaya Makmur villages, which have sandy soil, it is easier for people to dig the land for the grave, so it does not need much time to prepare it. On the other hand, in Popalia people need wider space and longer time to make a preparation. It is like preparing a house. The tombstone is wider than the ordinary one, which serves for the whole family. On one grave, there can be some tombstones, which show that the number of the dead buried there is more than one. That is why it is called the "second house" of the family.

The building of family's tombstone (Popalia model) is affected by the barren natural environment. On the rocks a hole would be made as the place for the corpse. Because it is difficult to dig deeper, the tombstone is made like a house foundation of $50-100 \mathrm{~cm}$ height on the rock. The corpse is put in the grave and then buried with sand mixed with a little greyish yellow soil to make a mound. If the sand is bright in colour, it shows that the corpse has just been buried. On the other hand, if the mound is darker, the corpse has long been buried. In this case, long before a person passes away, the grave is already prepared.

\section{THE BLACKSMITHS ISLANDS}

\section{AREA IDENTITY}

In the Dutch colonial time, the islands in Southeast Sulawesi were called Toekang besi eilanden, which was a territory of Buton monarchy (Ligtvoet 1878: 3, 113). In 1924, the Ducth East Indies divided the territory of Sulawesi government and its subdivisions into eight regions (afdeling), among others, were afdeling Buton and Laiwoei. The Blacksmiths Islands were one of the four sub-divisions of afdeling Buton and Leiwoi (Said 1997: 58). Then, when Sulawesi residency and its subdivisions changed into South Sulawesi residency in 1949, this area was still part of afdeling Buton until 1950.

The use of the name "Blacksmith" referred to two meanings. First, it is related to the name of the leader of the Hitu people's resistance in Maluku, Kapitan Telukabessi, in the first half of the seventeenth century (Pattikayhatu et al. 1983: 39-41). After being defeated, the followers of Telukabessi escaped to Buton. They lived in Kapota Island, near Wangi-wangi. They chose this area due to the knowledge about Buton. Geographically, these islands are connected with Maluku via the Banda Sea. From the beginning, the people of the Blacksmiths have been sailors. They arrived in Maluku before the arrival of European people and became the people of Maluku. In other words, they were the followers of Telukabessi, or as the party that helped the refugees find the Blacksmith Islands. After some years in Buton, they fought the Dutch again. As a result, some of them went back to Maluku. Some went back to Hitu and some dropped by and stayed in Luhu (Hamid 2009: 11-13). The 
return to Maluku was made possible by the help of Buton people serving as their guides. This event could be a landmark of the spread of Buton people in Maluku, in which the migration of Buton people headed to southern Maluku. In the second half of the seventeenth century, Buton people had been found in various areas in southern Maluku, especially in Ambon and Seram (Knaap 2004: 71, 163). At present, their dwelling places are commonly found in Ambon city and its surrounding areas.

The second meaning is related to the people's occupation as blacksmiths. This was testified by a Dutch citizen, Hoger, when he visited Binongko. Along the journey, he listened to the iron moulding from morning to afternoon, and in some parts even until evening. The blacksmiths produced various types and sizes of machetes and knives. Therefore, these islands are called the Blacksmith Islands (Hamid 2011: 24). Activities of the blacksmiths are still found until now in Binongko. Various types of knives, especially machetes, long machetes, and gae-gae machetes, are sold in Maluku. Some blacksmiths live in Maluku, especially in Hitu area and its surrounding, producing machetes and selling them to the farmers there. The machetes are well-known as the "Binongko machetes".

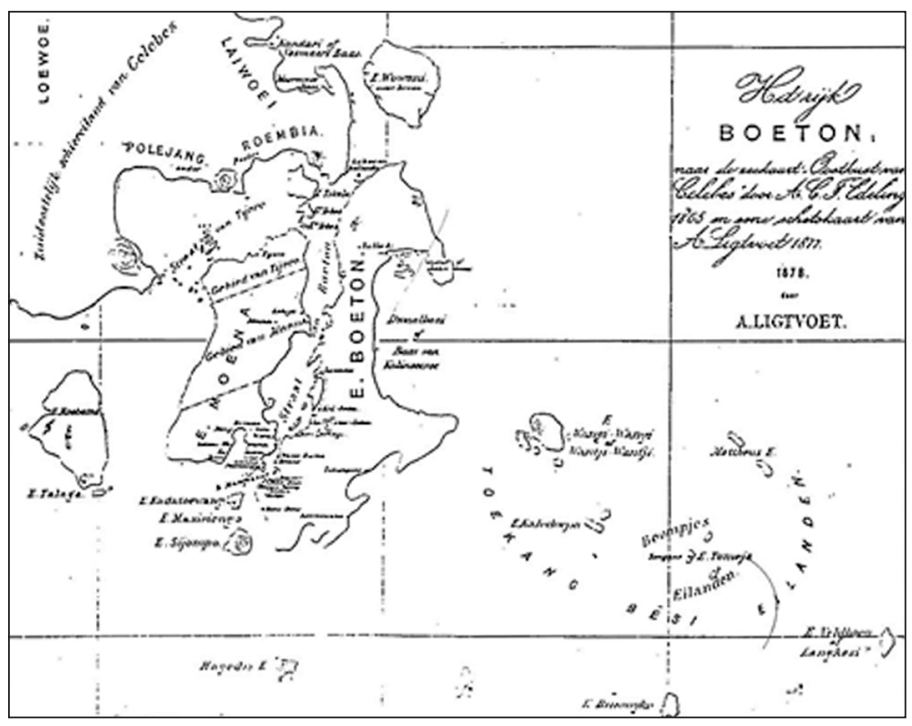

Map 2. Binongko Island in the Toekang besi eilanden 'Blacksmiths Islands' (Ligtvoet 1878).

In the second half of the twentieth century, in line with the formation of one single district in southeast Sulawesi, another identity was introduced for the Blacksmith Islands, namely Wakatobi, separated from Buton district. This name was reinforced when the central government legalized the formation of one new district in the Southeast Sulawesi Province, consisting of four islands, named Wakatobi district.

Before Wakatobi, Bitokawa identity had been introduced (an acronym of the name of the islands: Binongko, Tomia, Kaledupa, Wangi-Wangi), referring 
to the myth of La Patua and the princess. The placing of the word Bi (Binongko) in the beginning of the acronym Bitokawa refers more appropriately to the identity of the blacksmiths because from the past up to the present Binongko has been a place of the blacksmiths. Moreover, the emigrants' identity from these islands and Buton Island in general, including the blacksmiths, is better known as "Binongko". In this context, the Bitokawa identity is based on cultural aspects (the blacksmiths' tradition), while the Wakatobi identity refers to political aspects. In short, the use of the word "Wakatobi" for these islands shows a stronger political nuance than the cultural one.

\section{LOCAL PRODUCTION}

In mid-March 2015, I visited Binongko Island to see the blacksmiths' activities that have been done for hundreds of years. The target locations were Sowa and Popalia villages in Togo Binongko sub-district. From afar, we heard the clanging sound accompanied by the dangdut music. About 100 meters from the village border, we met a blacksmith, Rahman Nur a.k.a Rahman Bota, who has inherited his job since the first grade in elementary school 7 years old) from his parents. Rahman Bota had an electric machine to serve 64 metal industries in Sowa village, especially for daytime activities, with a rental fee of $\operatorname{Rp~10,000/day~since~the~state~electricity~company~(PLN)~only~provides~}$ electricity in the evening. Whereas the blacksmiths' activities are commonly done during the day and only few do them in the evening.

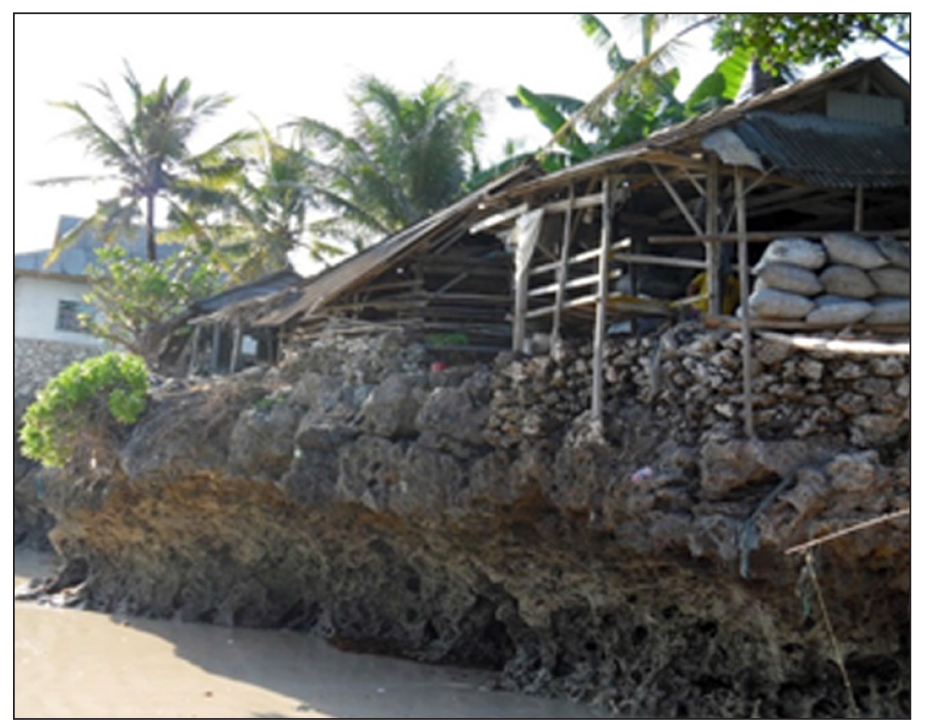

Picture 1. The area of Binongko machete making in Popalia coast (photography by Abd. Rahman Hamid, 2015).

The use of electricity was very important for the blacksmiths. In the past, there had to be a person, usually a woman, who was assigned to blow wind to the furnace. However, after the availability of electricity, especially with the use of blower, a pumper was no longer needed. Thus, electricity use reduced one labour. However, the production of machetes increased. Before using a 
blower, they could only produce a maximum of 20 machetes every day. After the use of the blower in 2013, they could produce more than 20 machetes. ${ }^{8}$

The blacksmiths' activities could be found almost everywhere, starting from the shorelines, in the neighbourhood, to the mountains. The clanging sound and music were heard all day long, except at noon between 12 and 13 p.m. as it was a break time for lunch and praying. The activities continued until late afternoon, namely about 5 p.m. Those who still wanted to work could continue their job after maghrib (namely a prayer done after the sunset, usually from 6 to 6.30 p.m.), from 7 to 10 p.m.

There are four types of machete in various sizes and functions produced by the blacksmiths. First, they are common machetes (Picture 2). They are about $50 \mathrm{~cm}$ long, top width 7-8 $\mathrm{cm}$ and middle/back width $4-5 \mathrm{~cm}$. These machetes are commonly used to cut small to medium wood. In Maluku, these machetes are much used by coconut farmers. Second, there are big machetes. The top part has the shape of an arc or a curve with a width of $8-9 \mathrm{~cm}$ and the middle/back width of $4-5 \mathrm{~cm}$, and $50 \mathrm{~cm}$. Their function is similar to common machetes, but these ones are very good for cutting or carving wood. That is why, they are commonly used by ship makers. Third, there are long machetes (common model and gae-gae, see Picture 3 and 4).9 The design of long machetes is similar to common machetes (the first type), but it is longer, namely $60-70 \mathrm{~cm}$, with a smaller width than common machetes which are 5-6 $\mathrm{cm}$ at the front side and $4-5 \mathrm{~cm}$ in the middle-back side. Gae-gae machete's length is almost the same with long machetes, but they differ in terms of their top model, which is curved inside about $5 \mathrm{~cm}$. These machetes are much used by farmers in Maluku to cut grass under and around clove trees. Fourth, there are short machetes (common model and machete). Their length is $20-30 \mathrm{~cm}$. They are much used to cut wood or other small things.

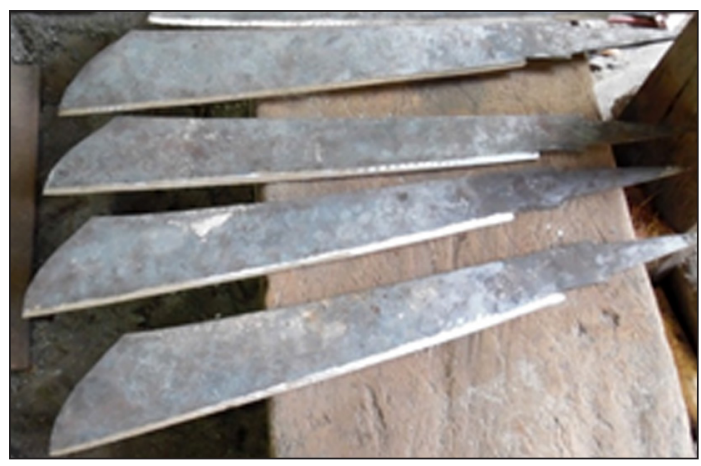

Picture 2. Types of common machetes (photography by Abd. Rahman Hamid, 2015).

An interview with La Simu (40 years old) and La Udin (40 years old) in Sowa, 20-3-

9 This term, used by the people in Maluku, came from gae meaning 'pull'. Thus, gaegae means 'pull again and again'. This term refers to the function of the front curve when it is used, namely to pull (gae) the grass being cut. 


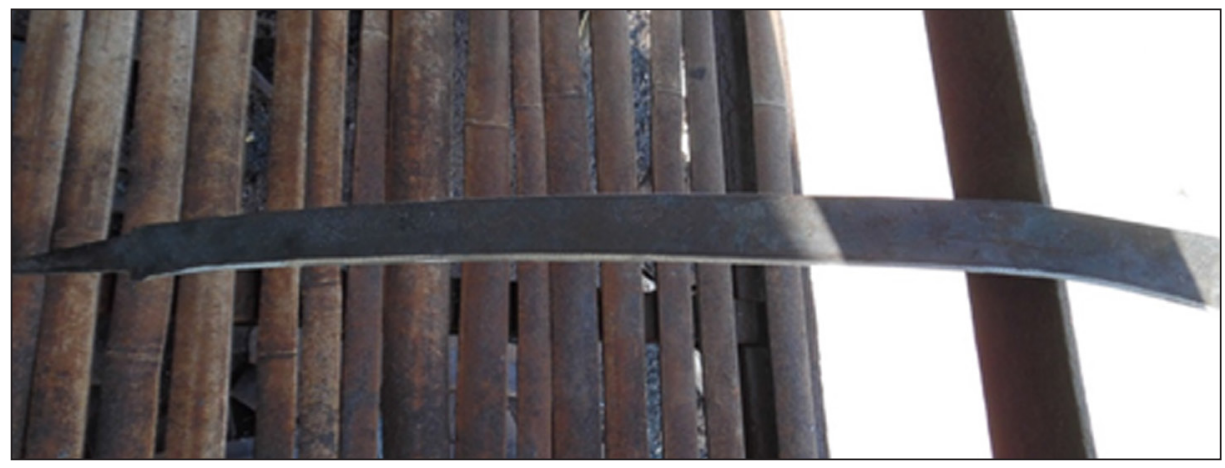

Picture 3. Long machete (photography by Abd. Rahman Hamid, 2015).

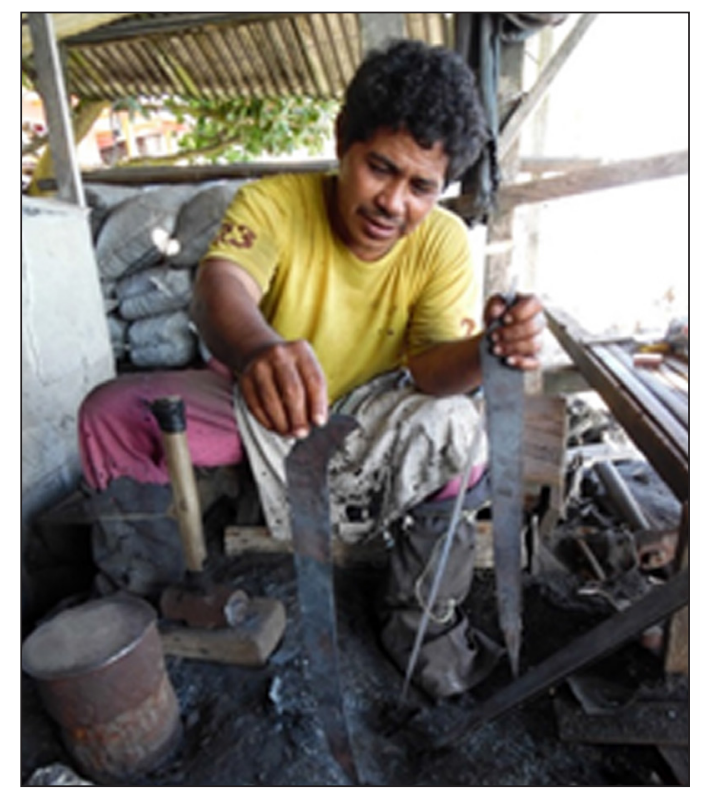

Picture 4. A blacksmith in Popalia was showing a long machete gae-gae (right hand) and common machete (left hand) (photography by Abd. Rahman Hamid, 2015).

Besides machetes, the blacksmiths also produce knives. Their size varies, with a length of 15-25 cm, and a width of 3-4 cm. Their forms look like thin machetes and common (machete) models. Besides being used as choppers in the kitchen, thin knives are considered as heirlooms. Knives are rarely marketed outside Binongko. Therefore, they are produced in a small quantity. Knife sale in Binongko is limited as a souvenir for guests. The knives that are sold have already been sharpened and put in their sheaths.

\section{IRON MERCHANT}

On May 19, 2007, motor sail boat (perahu layar motor shortened PLM in Indonesian) Kota Intan (35 ton), owned by La Ode Tarahaya, sailed from Wali 
Binongko village to Obi Island in North Maluku. There were 25 passengers, consisting of men and women. The majority of the passengers would pick cloves, except for one person who would only sell machetes. When asked, besides selling machetes, would he harvest cloves like the other passengers? He answered "no, I only wanted to sell machetes". After all of his machetes were sold, he went back to Binongko. At that time, he brought 50 machetes of various types and sizes, wrapped them in one gunnysack, which would be sold in North Maluku. ${ }^{10}$

Binongko machetes left a good impression among farmers in Maluku. Based on my observation in the 1990s and 2000s, buyers would not ask much after the seller said it was Binongko machetes. According to the farmers' testimony, Binongko machetes have good quality, with strong and sharp blades. That is why, Binongko machete sellers are always waited by every farmer each year.

Haji Kamil's experience, a machete seller from Rukuwa Binongko, might be useful to explain the marketing strategy used and the interaction between the seller and buyers in North Maluku. Before selling machetes, he had been actively sailing to North Maluku and Java for 15 years (1972-1987). Then for the next 12 years (1987-1999) he stayed in Singapore. In 2000-2003, he sold second-hand goods from Singapore to various areas, especially Maluku and Nusa Tenggara.

From October 2004 to 2015, Haji Kamil sold machetes. The shift was based on two considerations. First, there were not many competitors because the machete sellers were limited in number. Meanwhile, machetes are the primary need of the farmers in North Maluku. Second, the selling system was more profitable because there was no instalment system, like other goods. The buyers directly paid for the machetes. As a result, capital flow was smooth and profit target was clear.

Haji Kamil bought the machetes in Binongko. Initially, in 2004, the basic price of each machete was $\operatorname{Rp~15,000.~Then~it~was~sold~in~Tobelo,~North~}$ Maluku, for Rp 40,000-50,000 each. On one trip, he brought 2,000 machetes. He embarked on a wooden ship from Binongko that sailed directly to Ternate for 8 days. Then, he continued from Ternate to Tobelo with a speed boat for half a day. There, he stayed at a local person's house that he used as a selling place. He also went around the village to sell his machetes.

He used public transportation for going around. When arriving at a village, he carried his machetes in a certain quantity that he could manage, then sold them to the local people. He was often asked about the origin of the machetes. He answered "these machetes were from Binongko". According to him, Binongko machetes were well-known for their good quality. Two types of machetes he sold most were common machetes and long machetes.

10 An interview with a machete seller in Kota Intan ship, sailing at Banda Sea. I was on this voyage (for 4 days and three nights). Most of the passengers got off on Obi Latu island, two persons on Sanana island and one more (machete seller) continued sailing to Ternate (North Maluku). I myself continued to the western shore of Seram island. 
When selling them, Haji Kamil often made jokes to attract people's attention. He marketed his goods by displaying various performances related to the machetes. Usually he used the machete to split rocks or to cut nails. From the performance, if the machete got bent (tagulung), it showed that the quality was low. However, if the eye of the machete fractured (tapela), it showed that the machete was of good quality. In 2014, when someone only bought one piece, it cost Rp 100,000. However, if the buyer bought more than one, it could be discounted into Rp 80,000 each. Its initial investment was Rp 30,000 each. Early in 2015, he brought 800 machetes to North Maluku. After deducted by operational selling cost for three months, he got a profit around Rp 30,000,000.

While going around the village, Haji Kamil stayed with the local people, either a Moslem or a Christian. As a token of gratitude, he gave one machete to the host every time he came. During the stay, he also bought daily needs. In that way, the host was pleased, so he was welcome again in the next visit.

After he sold out his machetes, Haji Kamil went back to Buton, no longer on a wooden ship like the way he left, but on a PELNI ${ }^{11}$ ship to Bau-bau for two days/nights. Then, from Bau-bau he got on a motor ship to Binongko for about 8-10 hours. Besides him, his brother was also a machete seller, especially in Ternate city. They went there together, then they parted after the wooden ship arrived at Ternate. Besides Tobelo, Haji Kamil also went around throughout the Halmahera Island. Meanwhile, his brother peddled in Ternate city. The machete demand in other areas was supplied by another machete seller from Binongko.

\section{SAILING AND MIGRATION}

Sailing activities have opened the access to a lot of potentials in the destination area that could be utilized. At first, Binongko people visited an area for sailing and maritime trade. Then, after seeing the potentials, they decided to stay temporarily or for a long time there.

From 1950s to 1980s, when traditional sailing was in the heyday, Singapore and Malaysia were the two most visited areas by Binongko people. Their ships took copra from Maluku, during the east wind season. Their arrival was waited by their buyers, especially Chinese traders, whom they called tauke or toke (Hamid 2011). ${ }^{12}$

Java Island was the destination for Binongko ships, especially Probolinggo, Surabaya, Gresik, and Pasuruan. While waiting for the west wind season, the

11 Indonesian National Sailing Company.

12 Because sailing depended on the power of wind, they worked in the port or surrounding area while waiting for the west wind season. They worked various kinds of job to get additional income. That moment gave them a lot of profit because they did not need any capital but only labour and trust from the business people there. However, this moment was also risky, especially for those working outside the port because they were considered as "illegal visitors" by local security officers. In order to be safe, they worked in the port for tauke who bought their loading. In this case, the ship captain was entrusted to be the supervisor for the crew . 
sailors worked to unload the ship coming there and to load goods onto the ship. Daily need supplies, such as rice, fish, sugar, tea/coffee, and cigarettes were obtained from tauke who bought their loads. ${ }^{13}$

Out of all sailing and migration areas, Maluku was the main destination for Binongko people. Long before the heyday of copra trading in the twentieth century, they had migrated to Maluku (Knaap 2004). Different from Java, Singapore, and Malaysia, Binongko sailors in Maluku sailed and peddled around the island and villages. They were doing that while waiting for the east wind season, which helped them to sail to the western part of this country. In this way, they knew the condition of each area and its people, including the opportunity they could take in the future. That was the experience of Haji Kamil, who was initially a sailor and then turned to be a machete peddler in North Maluku.

Gradually, some sailors turned to be workers of the plantation owned by orang negeri. ${ }^{14}$ They were often trusted to toil on the local people's plantations. There were some who bought the land from orang negeri. This made them have some land. Then, the family members came from Binongko. Their number grew constantly. They stayed there and became part of the local people. This is one of the models of Binongko migration to Maluku, especially in the twentieth century. ${ }^{15}$

The next model takes place in a certain period and the people are commonly known as periodical immigrants because they came at a certain time, especially during the clove harvest time. Those who had stayed sent some news to their relatives in Binongko. Following the news, more periodical migrants went to Maluku. They became clove harvesters for Binongko people and also for orang negeri. Now, some orang negeri are clove harvesters for Binongko people. Thus, there is a change of social status for Binongko people, from workers to plantation owners. On the other hand, some orang negeri, including plantation owners, now become workers for Binongko people.

The shift from sailors to machete peddlers or farmers is not a choice for all people. For instance, La Isihaka and La Fole, who now live in Jaya Makmur village, Binongko, were not tempted to change their job. For them, the decision to have, own, and maintain ships could not be replaced by others, as a strategy to survive in the rock island. Ships are meant to earn for a living through sailing and trading. Therefore, ships are treated like "humans" that need attention and maintenance to keep them in good condition and ready to use for a living.

Even so, the two old sailors realized that there was a change in the new generation's way of thinking and behaviour. In the old days, many people

13 An interview with La Ode Tajuddin (62 years old) in Popalia, 17-3-2015.

14 This term is used by Binongko sellers and sailors to call the local (native) people of Maluku.

15 Before the twentieth century, Binongko migrants were still limited in number. In the nineteenth century for instance, they were imported to Maluku as labors by the Dutch. In the early twentieth century, many Binongko trading sailors got involved in copra maritime freight trading. This activity brought them closer to the condition and potential of Maluku. 
chose to be sailors, as known through a famous saying "sailing gave you money, but going to school wasted money". But now, only few children want to become sailors. Binongko children prefer going to school to sailing. It is true that they cannot get a quick profit like what sailors would get, but they believe that it can guarantee their future, even more if they become civil servants (pegawai negeri sipil shortened PNS in Indonesian). Therefore, although he is old now, La Isihaka still wanted to accompany his child, acting as the captain to continue their family's maritime business. Only few people think like La Isihaka and his family now.

The shift does not change the substance of their way of life as emigrants. Some Binongko children, after graduating from junior high school, continue their study outside the island, especially to Buton and Kendari. Up to the present, there is no university in Wakatobi district. Thus, to continue their study, they have to emigrate to Buton, Kendari, Maluku, Makassar, and some cities in Java. In this context, if the cities had been visited by the sailors for trade in the past, now they become places for their descendants to study. In short, there is a change of life orientation, from sailors (pahela/palangke) to students (pasikola), to survive in the rock island.

\section{CONCLUSION}

Surviving in the rock island was not easy. It took strong attitude and mentality. Binongko people have tried many things to survive, among others, by creating a myth (La Patua and the princess) as a foundation of cultural legitimization. Through myth, they presented themselves independently as people of an island who speak the island's language. From the two figures, Cia-cia and Kaumbedha identities were created. This myth also describes the spread of the early community from Binongko to other islands in Wakatobi. Binongko is allegorized as a head that has the main function of the human body. This view is supported by a religious belief that Binongko is the gateway for the spread of Islam and the birthplace of ulamas who work actively in Southeast Sulawesi, Maluku, and Irian Jaya.

Behind the grandeur of the mythical spiritual story, Binongko geographically is the most barren and underdeveloped area in Wakatobi. People cannot expect much from its natural resources. Farming cycle takes a longer time because this island mainly consists of rocks. Cassava cultivation, which is commonly planted on fertile ground and grows less than one year, in this place may take one year or longer. Making "the second house" (burial ground) is more difficult than making the first one, and it takes one month or longer (Popalia's case). Although there are rock holes, corpses cannot be buried in there since they are the source of water.

Up to the present, most of the people's needs have been imported from beyond the sea. This condition gives rise to creative mind and action, as a "survival strategy", that is to survive especially by sailing and trading. For them, the sea is a medium for making a living, so they will do many things to sail over the sea. Being a blacksmith is one of the creative survival strategies 
in the rock island, also as a supporting sailing activity. Due to this sailing tradition, as testified by the Dutch when visiting or passing by that island on a voyage from and to Maluku, which still continues until today, Binongko Island is known as the Blacksmith Island. The old Wakatobi's identity, as the Blacksmiths Island, is actually from Binongko. This has strengthened their identity as a group of people who are "superior" to others. In fact, Binongko's identity, especially in Maluku, refers to all Buton people. As a matter of fact, according to Susanto Zuhdi (2014), Buton's maritime characteristics actually originated from Binongko.

The survival ability in the rock island is proof of Binongko people's success in responding to the harsh natural conditions they face. The natural hardship and difficult life conditions have brought about resilient mentality. Sailing and trading activities among the islands are the main source of income, besides their activity as blacksmiths. Because of that, Binongko people have spread to many other areas in this country.

\section{REFERENCES}

BPS. 1982. Kabupaten Buton dalam angka. Bau-Bau: Kantor Statistik Kabupaten Buton.

BPS. 1987. Kabupaten Buton dalam angka. Bau-Bau: Kantor Statistik Kabupaten Buton.

Coppenger, Caleb. 2012. Misteri Kepulauan Buton menurut sesepuh dan saya. Jakarta: Adonai.

Hadara, Ali et al. 2014. Etnografi suku-suku di Wakatobi. Kendari: UD Mapan. Hamid, Abd. Rahman. 2009. "Dari Telukabessy sampai Kepulauan Tukang Besi", Majalah Sureq Seni dan Budaya, pp. 10-12. Makassar: La Galigo Press.

Hamid, Abd. Rahman. 2011. Orang Buton; Suku bangsa bahari Indonesia. Yogyakarta: Ombak.

Knaap, Gerrit. 2004. Kruidnagelen en Christenen; De VOC en de bevolking van Ambon 1656-1696. Leiden: KITLV Uitgeverij.

Ligtvoet, A. 1878. "Beschrijving en geschiedenis van Boeton", BKI 26: 1-112. Mbaru, La Rabu. 2005. "Hikayat Haebu Kepulauan Bitokawa Butuni". [Unpublished manuscript.]

Noorduyn, J. 1991. A critical survey of studies on the languages of Sulawesi. Leiden: KITLV Press.

Pattikayhatu, John A. et al. 1983. Sejarah perlawanan terhadap imperialisme dan kolonialisme di daerah Maluku. Jakarta: Departemen Pendidikan dan Kebudayaan.

Poerwanto, Hari. 2005. Kebudayaan dan lingkungan dalam perspektif antropologi. Yogyakarta: Pustaka Pelajar.

PPSK UGM. 1980. Sensus penduduk 1961; Penduduk desa Sulawesi dan Maluku. Yogyakarta: Pusat Penelitian dan Studi Kependudukan Universitas Gadjah Mada.

Said, D. 1997. "Pembentukan Provinsi Sulawesi Tenggara 1950-1978; Studi konflik dan integrasi", Master thesis, Universitas Indonesia. 
Zahari, Abdul Mulku. 1977. Sejarah dan adat fiy Darul Butuni (Buton) Vol. III. Jakarta: Departemen Pendidikan dan Kebudayaan.

Zuhdi, Susanto. 2014. Laut, nasionalisme, dan sejarah. Jakarta: Komunitas Bambu.

\section{INTERVIEW}

Haji Kamil (60 years old) in Rukuwa village, 19-3-2015.

Haji Rusdin (60 years old) in Popalia village, 20-3-2015.

La Banisa (50 years old) in Haka village, 17-3-2015.

La Fole (80 years old) in Jaya Makmur village, 21-3-2015.

La Gani S (79 years old) in Taipabu village, 18-3-2015.

La Isihaka (73 years old) in Jaya Makmur village, 21-3-2015.

La Malihu (54 years old) in Makassar city, 21-7-2015.

La Ode Tajuddin (62 years old) in Popalia village, 17-3-2015.

La Rabu Mbaru (52 years old) in Wali village, 16-3-2015.

La Simu (40 years old) in Sowa village, 20-3-2015.

La Udin (40 years old) in Sowa village, 20-3-015.

Rahman Nur (29 years old) in Sowa village, 20-3-2015. 